\title{
Stigma dan Diskriminasi Orang Dengan HIV/AIDS Antara Masyarakat Perkotaan dan Pedesaan Di Sulawesi Selatan
}

\author{
Stigma and Discrimination of People With HIV / AIDS Between Urban and Rural Communities \\ in South Sulawesi
}

\author{
Sri Handayani ${ }^{1}$, Akmal Mahmud ${ }^{2}$ \\ ${ }^{1}$ Program Studi Kesehatan Masyarakat, Sekolah Tinggi Ilmu Kesehatan (STIK) Tamalatea Makassar \\ ${ }^{2}$ BKKBN Provinsi Sulawesi Selatan \\ e-mail: *srihandayani@stiktamalateamks.ac.id
}

\begin{abstract}
Abstrak
HIVIAIDS merupakan penyakit yang masih menjadi masalah kesehatan masyarakat di seluruh dunia baik ditinjau dari segi kesehatan, politik, maupun sosial ekonomi. Di Indonesia, jumlahnya terus meningkat sehingga menjadi tantangan berat untuk mencapai tujuan pembangunan berkelanjutan (SDGs) hingga tahun 2030. Sulawesi Selatan menempati urutan keempat dalam hal jumlah kasus AIDS terbanyak baik di pedesaan maupun perkotaan.Berbagai upaya pencegahan dan penanggulangan HIVIAIDS telah dilakukan, namun permasalahan stigma dan diskriminasi seringkali menjadi hambatan dalam upaya menurunkan prevalensi HIVIAIDS. Tujuan penelitian ini adalah untuk mengetahui perbedaan stigma dan diskriminasi OHA antara masyarakat perkotaan dan pedesaan di Sulawesi Selatan . Penelitian ini merupakan penelitian observasional analitik dengan menggunakan data Survei Demografi dan Kesehatan Indonesia (SDKI) Provinsi Sulawesi Selatan tahun 2017 tentang HIVIAIDS. Waktu penelitian dilaksanakan pada bulan Mei - Oktober 2019. Data dianalisis dengan uji statistik univariat dan uji statistik lanjut dengan menggunakan Uji Independent Samples Test dengan derajat kepercayaan $95 \%$. Hasil penelitian ditemukan bahwa ada perbedaan signifikan pengetahuan tentang HIVIAIDS $(p-v a l u e=0.003)$, sumber informasi $(p-$ value $=0.001)$ dan stigma atau diskriminasi terhadap orang dengan HIVAIDS $(p$-value $=0.000)$ antara masyarakat perkotaan dan pedesaan di Sulawesi Selatan. Sedangkan sikap negosiasi berhubungan seksual yang aman dengan suami tidak memiliki perbedaan yang signifikan terhadap masyarakat perkotaan dan pedesaan di Sulawesi Selatan dengan niai $p$ value $=0.699$. Diharapkan kepada semua intansi baik pemerintah maupun swasta agar dapat berperan aktif dalam pemecahan masalah HIVIAIDS secara komprehensif. Selain itu pada masyarakat pedesaan peran aktif tokoh masyarakat, tokoh adat dan pemuka agama sangat besar pengaruhnya dalam menurunkan terjadinya stigma dan diskriminasi terhadap ODHA karena tokoh-tokoh lokal tersebut merupakan model atau contoh yang biasanya menjadi panutan masyarakat.
\end{abstract}

Kata kunci: Stigma, Diskriminasi, HIVIAIDS, Perkotaan, Pedesaan.

\begin{abstract}
HIV / AIDS is a disease that is still a public health problem around the world from a health, political, and socio-economic perspective. In Indonesia, the number continues to increase, making it a tough challenge to achieve the sustainable development goals (SDGs) by 2030. South Sulawesi ranks fourth in terms of the highest number of AIDS cases both in rural and urban areas. Various efforts to prevent and control HIV / AIDS have been carried out, however, the problems of stigma and discrimination often become obstacles to efforts to reduce the prevalence of HIV / AIDS. The aims of this study was to determine the differences in OHA stigma and discrimination between urban and rural communities in South Sulawesi. This research is an analytical observational study using data from the 2017 South Sulawesi Demographic and Health Survey (IDHS) on HIV / AIDS. The research was conducted in May - October 2019. The data were analyzed using univariate statistical tests and further statistical tests using the Independent Samples Test with a $95 \%$ degree of confidence. The results of the study found that there were significant differences in knowledge about HIV / AIDS ( $p$ value $=0.003$ ), sources of information ( $p$-value $=0.001$ ) and stigma or discrimination against people with HIV $/$ AIDS $(p$-value $=0.000)$ between urban and rural communities in South Sulawesi. Meanwhile, the attitude of negotiating safe sexual intercourse with husbands did not have a significant difference in urban and rural communities in South Sulawesi with a p-value $=0.699$. It is hoped that all agencies, both government and private, can play an active role in solving the HIV / AIDS problem comprehensively. In addition, in rural communities the active role of community leaders, traditional leaders and religious leaders is very influential in reducing the occurrence of stigma and discrimination against PLWHA because these local figures are models or examples that usually become role models for the community.
\end{abstract}

Keywords: Stigma, Discrimination, HIV / AIDS, Urban, Rural.

\section{Pendahuluan}


Infeksi Menular Seksual (IMS) masih menjadi masalah kesehatan masyarakat di seluruh dunia baik dilihat dari segi kesehatan, politik, ataupun sosial ekonomi. Diperkirakan terdapat sekitar 340 juta atau lebih penderita IMS. ${ }^{1}$ IMS juga menjadi salah satu penyebab morbiditas dan mortalitas pada ibu dan bayinya, dimana IMS dapat menyebabkan kehamilan ektopik, penyakit radang panggul pada ibu, bayi prematur, keguguran, bayi lahir mati, peningkatan penyebaran HIV serta penyakit lainnya. ${ }^{2}$

Human Immuno-deficiency Virus (HIV) merupakan sejenis virus yang menyerang sel darah putih sehingga menyebabkan turunnya kekebalan tubuh. Sedangkan Aqquired Immuno Deficiency Syndrome (AIDS) merupakan sekumpulan gejala penyakit yang muncul karena menurunnya sistem kekebalan tubuh manusia yang disebabkan oleh virus HIV. HIV/AIDS masih menjadi masalah global kesehatan masyarakat. Tercatat sampai tahun 2017, lebih dari 36,9 juta jiwa menderita dengan HIV. Jumlahnya semakin meningkat sehingga menjadi tantangan berat untuk mencapai tujuan pembangunan berkelanjutan (SDGs) hingga tahun $2030 .^{3}$

Menurut data World Health Organization (WHO) 2017, di beberapa benua seperti Afrika 25,7 juta jiwa, Amerika 3,4 juta jiwa, Asia 3,5 juta jiwa menderita HIV. Dan di Asia Tenggara juga memiliki kasus HIV/AIDS seperti Myanmar, Thailand, Malaysia dan Indonesia. ${ }^{4}$ Di Indonesia, hingga saat ini diprediksi kasus HIV AIDS sudah menyebar di 407 kabupaten/kota dan kurang lebih 80 persen dari seluruh kabupaten/kota di Indonesia. 10 besar kasus HIV terbanyak ada di Sulawesi Selatan. ${ }^{5}$ Sulawesi Selatan menempati urutan keempat kasus AIDS terbanyak dan telah ditemukan baik di pedesaan maupun perkotaan. ${ }^{3}$

Kasus HIV/AIDS di Sulawesi Selatan berada pada usia produktif berstatus anak sekolah, mahasiswa dan pekerja dimanapada kelompok usia 15-19 tahun dan usia20-29 tahun. Beberapa faktor risiko penularan HIV/AIDS diantaranya pengetahuan tentang HIV AIDS, sikap dan perilaku penyimpangan seksual, penyalagunaan narkoba suntik atau (IDU), jumlah pasangan seksual, media, usia saat berhubungan seksual pertama kali. Disamping itu telah terjadi pergeseran dalam cara penularannya yang semula oleh penyalagunaan narkoba suntik/Injecting Drug User (IDU), dan kasus penularan HIV dan AIDS terbanyak yaitu sebesar 50,4\% pada heteroseksual, dan 3,89\% pada homoseksual. ${ }^{5}$

Upaya pencegahan dan penanggulangan HIV/AIDS telah dilaksanakan, tetapi stigma dan diskriminasi masih menjadi masalah utama terhadap keluarga ataupun orang dengan HIV/AIDS. Stigma dan diskriminasi ODHA dan keluarganya menjadi hambatan dalam menurunkan angka kejadian HIV/AIDS..$^{5}$ Kurangnya informasi tentang penyebab dan penularan HIV/AIDS menjadi stigma buruk yang ada dalam diri ODHA ataupun keluarganya. Perilaku diskriminasi seperti pemisah atau menolak ODHA dan keluarganya di lingkungan keluarga, lingkungan kerja, ataupun di lingkungan sosial. Ini dikarenakan masyarakat menganggap virus HIV/AIDS itu penyakit menular berbahaya dan belum memahami proses penularannya. ${ }^{6}$

Kasus HIV/AIDS mengalami peningkatan sebesar 64,50\% pada tahun 2019 dan menyebar baik di perkotaan ataupun di pedesaan sehingga membutuhkan perhatian dan penanganan yang komprehensif dengan melibatkan semua elemen Masyarakat Internasional dan juga PBB. ${ }^{6}$ Epidemi HIV/AIDS membuat dampak buruk pada pembangunan nasional secara keseluruhan dan juga terhadap masalah sosial ekonomi bangsa Indonesia. ${ }^{7}$ Berdasarkan latar belakang maka pertanyaan penelitian ini adalah bagaimana perbedaan Stigma dan Diskriminasi Orang dengan HIV/AIDS antara Masyarakat Perkotaan dan Pedesaan di Sulawesi Selatan.

\section{Metode Penelitian}


Penelitian ini merupakan penelitian observasional analitik dengan menggunakan data sekunder Survei Demografi dan Kependudukan Indonesia (SDKI) Provinsi Sulawesi Selatan tahun 2017 Pemilihan lokasi didasarkan karena Sulawesi Selatan masuk ke dalam 10 besar Provinsi dengan angka kejadian HIV/AIDS tertinggi di Indonesia. Waktu pelaksanaan penelitian adalah Mei-Agustus 2019. Populasi pada penelitian ini adalah seluruh data Survei Demografi dan Kesehatan Indonesia (SDKI) tahun 2017 Provinsi Sulawesi Selatan dan sampel yang diambil adalah data tentang HIV/AIDS. Metode pengambilan sampel dalam penelitian ini adalah purvosive sampling yang merupakan salah satu metode teknik pengambilan sampel non random sampling dimana peneliti menentukan pengambilan sampel dengan cara menetapkan sendiri ciri khusus sesuai tujuan penelitian. Oleh karena itu, sesuai tujuan penelitian, maka sampel dalam penelitian ini adalah seluruh data penderita HIV/AIDS pada data SDKI Provinsi Sulawesi Selatan tahun 2017.

Analisis data dilakukan dengan uji statistic Independen sample t-test. Independen T Test merupakan uji beda untuk mengetahui adakah ada perbedaan mean atau rerata yang signifikan antara 2 kelompok bebas atau tidak saling mempengaruhi yang berskala data interval/rasio. Dua kelompok bebas yang dimaksud adalah masyarakat perkotaan dan pedesaaan mengenai stigma dan diskriminasi ODHA.

\section{Hasil}

Data hasil SDKI 2017 tingkat provinsi Sulawesi Selatan diperoleh dari hasil wawancara dengan wanita umur 15-49 tahun dan pria kawin umur 15-54 tahun menurut daerah perkotaan dan perdesaan.

Tabel 1. Distribusi jumlah rumah tangga, jumlah kunjungan dan hasil kunjungan, menurut tempat tinggal (tidak tertimbang), Provinsi Sulawesi Selatan 2017

\begin{tabular}{lccr}
\hline & \multicolumn{2}{c}{ Tempat Tinggal } & \multirow{2}{*}{ Total } \\
\cline { 2 - 3 } Hasil & Perkotaan & Perdesaan & \\
\hline Wawancara rumah tangga & 800 & 952 & 1.752 \\
Rumah tangga sampel & 774 & 935 & 1.709 \\
Rumah tangga ditemui & 764 & 930 & 1.694 \\
Rumah tangga diwawancarai & 98,7 & 99,5 & 99,1 \\
Hasil kunjungan & & & \\
Wawancara perseorangan & & 979 & 1.926 \\
wanita & 947 & 952 & 1.873 \\
Wanita yang memenuhi syarat & 921 & 97,2 & 97,2 \\
Wanita yang diwawancarai & 97,3 & & 346 \\
Hasil kunjungan & & & \\
Wawancara perseorangan pria & & 194 & 321 \\
Pria yang memenuhi syarat & 152 & 182 & 92,8 \\
Pria yang diwawancarai & 139 & 93,8 & \\
Hasil kunjungan & & &
\end{tabular}

Secara umum, tabel 1 memperlihatkan hasil kunjungan rumah tangga dan perseorangan relatif tinggi. Dari 1.752 rumah tangga terpilih SDKI 2017, sebanyak 1.709 rumah tangga ditemukan, dan 
dari jumlah tersebut sebanyak 1.694 atau 99,1 persen rumah tangga berhasil diwawancarai. Dari 1.694 rumah tangga yang diwawancarai, terdapat 1.926 wanita yang memenuhi syarat untuk diwawancarai, dan sebanyak 1.873 wanita yang berhasil diwawancarai menghasilkan tingkat respon sebesar 97,2 persen. Dari rumah tangga terpilih sampel pria kawin, terdapat 346 pria yang memenuhi syarat untuk diwawancarai, dan yang berhasil diwawancarai ada 321 pria, menghasilkan tingkat respon sebesar 92,8 persen. Tingkat respon pria yang lebih rendah disebabkan pria lebih sering tidak dapat dijumpai saat wawancara. Secara umum, tingkat respon wawancara pria kawin di daerah perdesaan relatif lebih tinggi daripada di daerah perkotaan.

Tabel 2. Distribusi Persentase Jawaban Wanita umur 15-49 dan Pria Kawin Umur 40 -49 tentang Perilaku diskriminatif terhadap orang yang hidup dengan HIV AIDS, Berdasarkan Tempat Tinggal Provinsi Sulawesi Selatan 2017

\begin{tabular}{|c|c|c|c|}
\hline \multirow{2}{*}{ No } & \multirow{2}{*}{ Pertanyaan } & \multicolumn{2}{|c|}{ Persentase Jawaban } \\
\hline & & Perkotaan & Pedesaan \\
\hline 1 & $\begin{array}{l}\text { Persentase yang tidak sependapat bahwa anak } \\
\text { yang menderita HIV AIDS boleh bersekolah } \\
\text { dengan anak yang bukan penderita HIV AIDS }\end{array}$ & 37.3 & 37,4 \\
\hline 2 & $\begin{array}{l}\text { Persentase yang tidak mau membeli sayuran } \\
\text { segar dari penjual yang terinfeksi HIV }\end{array}$ & 68,7 & 70,6 \\
\hline 3 & $\begin{array}{l}\text { Persentase yang merahasiakan anggota } \\
\text { keluarga yang terinfeksi HIV }\end{array}$ & 57,1 & 61,4 \\
\hline 4 & $\begin{array}{l}\text { Persentase yang tidak mau merawat anggota } \\
\text { keluarga yang terinfeksi HIV }\end{array}$ & 25,8 & 22,4 \\
\hline 5 & $\begin{array}{l}\text { Jumlah responden yang pernah mendengar } \\
\text { tentang HIV AIDS }\end{array}$ & 484 & 652 \\
\hline 6 & $\begin{array}{l}\text { Persentase yang tidak sependapat bahwa anak } \\
\text { yang menderita HIV AIDS boleh bersekolah } \\
\text { dengan anak yang bukan penderita HIV AIDS }\end{array}$ & 29,5 & 26,0 \\
\hline 7 & $\begin{array}{l}\text { Persentase yang tidak mau membeli sayuran } \\
\text { segar dari penjual yang terinfeksi HIV }\end{array}$ & 58,8 & 59,3 \\
\hline 8 & $\begin{array}{l}\text { Persentase yang merahasiakan anggota } \\
\text { keluarga yang terinfeksi HIV }\end{array}$ & 38,4 & 44,9 \\
\hline 9 & $\begin{array}{l}\text { Persentase yang tidak mau merawat anggota } \\
\text { keluarga yang terinfeksi HIV }\end{array}$ & 19,9 & 15,0 \\
\hline 10 & $\begin{array}{l}\text { Persentase sikap diskriminasi terhadap } \\
\text { pengidap HIV }\end{array}$ & 90,5 & 92,3 \\
\hline
\end{tabular}

Sumber: SDKI, 2017 
Tabel 2 diketahui bahwa persentase perilaku diskriminatif terhadap orang yang hidup dengan HIV AIDS, berdasarkan tempat tinggal di Provinsi Sulawesi Selatan lebih besar di daerah pedesaan. Misalnya pada masyrakat pedesaan ada 70,6 \% yang tidak membeli sayuran segar dari penjual yang terinfeksi HIV deibandingkan dengan masyarakat perkotaan yaitu sebesar $68,7 \%$. Dan secara umum persentase sikap diskriminasi terhadap pengidap HIV di perkotaan sebesar $90,5 \%$ dan pedesaan sebesar $92,3 \%$.

Tabel 3. Deskripsi Perbedaan Mean dan Standar Deviasi Stigma atau Deskriminasi terhadap Orang dengan HIVAIDS pada Masyarakat Perkotaan dan Pedesaaan Provinsi Sulawesi Selatan 2017

\begin{tabular}{lcccc} 
& Daerah & Mean & Std. Deviation & $\begin{array}{c}\text { Std. Error } \\
\text { Mean }\end{array}$ \\
\hline Diskriminasi & Perkotaan & 46.3950 & 14.09320 & 3.15134 \\
& Pedesaan & 71.6550 & 18.70993 & 4.18367 \\
\hline
\end{tabular}

Sumber: SDKI, 2017

Berdasarkan tabel 3 dapat diketahui perbedaan mean sumber informasi masyarakat pedesaaan dan perkotaan dimana nilai mean diskriminasiterhadap orang dengan HIVAIDS pedesaan lebih tinggi yaitu 71.6550 dengan nilai standar deviasi 14.09320 dibandingkan nilai mean masyarakat perkotaan yaitu 71.6550 dengan nilai standar deviasi 18.70993.

Tabel 4. Hasil Analisis Statistik Uji Independent Samples Test Tentang Stigma atau Deskriminasi terhadap Orang dengan HIVAIDS pada Masyarakat Perkotaan dan Pedesaaan Provinsi Sulawesi Selatan 2017

\begin{tabular}{|c|c|c|c|c|c|c|c|c|c|c|}
\hline \multicolumn{4}{|c|}{$\begin{array}{c}\text { Levene's Test for Equality of } \\
\text { Variances }\end{array}$} & \multicolumn{7}{|c|}{ t-test for Equality of Means } \\
\hline & & \multirow[b]{2}{*}{$\mathbf{F}$} & \multirow[b]{2}{*}{ Sig. } & \multirow[b]{2}{*}{$\mathbf{T}$} & \multirow[b]{2}{*}{ df } & \multirow{2}{*}{$\begin{array}{c}\text { Sig. } \\
(2- \\
\text { tailed })\end{array}$} & \multirow{2}{*}{$\begin{array}{c}\text { Mean } \\
\text { Differenc } \\
\text { e }\end{array}$} & \multirow{2}{*}{$\begin{array}{c}\text { Std. } \\
\text { Error } \\
\text { Differenc } \\
\text { e }\end{array}$} & \multicolumn{2}{|c|}{$\begin{array}{l}95 \% \text { Confidence } \\
\text { Interval of the } \\
\text { Difference }\end{array}$} \\
\hline & & & & & & & & & Lower & Upper \\
\hline \multirow[t]{2}{*}{$\begin{array}{l}\text { Diskrimina } \\
\mathrm{si}\end{array}$} & $\begin{array}{c}\text { Equal } \\
\text { variances } \\
\text { assumed }\end{array}$ & 5.419 & .225 & -4.82 & 38 & .000 & -25.26 & 5.2 & -35.8 & -14.3 \\
\hline & $\begin{array}{c}\text { Equal } \\
\text { variances } \\
\text { not } \\
\text { assumed }\end{array}$ & & & -4.82 & & .000 & -25.26 & 5.2 & -35.8 & -14.4 \\
\hline
\end{tabular}

Sumber: SDKI, 2017

Berdasarkan tabel 4. ketahui nilai Levene's Test for Equality of Variances adalah 0,225>0,05 maka dapat diartikan bahwa varians data stigma dan diskriminasi antar masyarakat perkotaan dan 
pedesaan adalah homogen atau sama. Sehingga penafsiran tabel output Independent Sampel Test diatas berpedoman pada nilai yang terdapat dalam tabel "Equal variances assumed"Tabel Independent Sampel Test pada bagian "Equal Variance Assumsed" diketahui nilai Sig. (2-tailed) sebesar $0.000<0,05$, maka dapat disimpulkan bahwa Ho diterima dan Ha ditolak. Artinya ada perbedaan signifikan Stigma atau Deskriminasi terhadap Orang dengan HIVAIDS pada Masyarakat Perkotaan dan Pedesaaan Provinsi Sulawesi Selatan.

\section{Pembahasan}

Stigma terhadap ODHA dalam penelitian ini adalah sikap dan perilaku negatif seseorang apabila berhadapan dengan ODHA pada masyarakat perkotaan dan pedesaan Provinsi Sulawesi Selatan. Hasil penelitian menunjukkan 9 dari $10(92 \%)$ wanita dan 84 persen pria kawin bersikap diskriminatif terhadap orang yang terinfeksi HIV. Sikap diskriminasi terhadap orang yang terinfeksi HIV ini kemungkinan besar berkaitan dengan ketidaktahuan seseorang tentang mekanisme penularan HIV. Kesalahpahaman atau kurangnya pengetahuan tentang HIV-AIDS seringkali berdampak pada ketakutan dan penolakan masyarakat terhadap ODHA.

Berdasarkan uji statistik lanjut diketahui nilai Sig. (2-tailed) sebesar $0.000<0,05$, maka dapat disimpulkan bahwa ada perbedaan signifikan Stigma atau Deskriminasi terhadap Orang dengan HIVAIDS pada Masyarakat Perkotaan dan Pedesaaan Provinsi Sulawesi Selatan. Stigma dan diskriminasi terhadap ODHA masih banyak terjadi dimasyarakat pedesaan. Hal ini terlihat dari hasil penelitian yang menunjukkan hampir separuh dari responden $(49,7 \%$ ) memiliki sikap negatif terhadap ODHA. Bentuk stigma yang terjadi dimasyarakat seperti tidak makan makanan yang disediakan atau dijual oleh penderita HIV, tidak membolehkananaknya anaknya bermain bersama dengan anak penderita HIV, tidak mau menggunakan toilet bersama, ataupun menolak untuk tinggal dekat dengan orang yang menunjukkan gejala penderita HIV/AIDS. Apabila dalam keluarga terdapan penderita HIV, mereka takut tidur bersama dan tidak bersedia merawat seperti menyiapkan makanan dan membersihkan peralatan makan,ataupun duduk dekat dengan orang-orang terinfeksi HIV.

Penelitian ini sejalan dengan penelitian yang dilakukan oleh Xin $\mathrm{Li}$, et al mengemukakan bahwa peserta yang memiliki sikap stigma terhadap ODHA adalah 49,6\% di antara responden pedesaan dan $37,0 \%$ di antara responden perkotaan $(\mathrm{P}<0,001)$. Analisis regresi binomial log multivariat antara masyarakat pedesaan $(\mathrm{RR}=0,89,95 \% \mathrm{CI}: 0,87-0,91, \mathrm{P}<0,001)$ dan peserta perkotaan $(\mathrm{RR}=0,89$, 95\% CI: 0,87-0,91, P <0,001) menunjukkan bahwa pengetahuan yang lebih besar kesalahpahaman penularan HIV secara signifikan terkait dengan sikap stigma yang lebih rendah terhadap ODHA. Di antara masyarakat perkotaan, tingkat pendidikan yang lebih tinggi (sekolah menengah vs sekolah dasar atau kurang: $\mathrm{RR}=0,73,95 \% \mathrm{CI}$ : 0,62-0,87, $\mathrm{P}<0,001$; sekolah menengah vs sekolah dasar atau kurang: $\mathrm{RR}=0,83,95 \% \mathrm{CI}: 0,71-0,97, \mathrm{P}=0,018)$ juga secara bermakna dihubungkan dengan sikap stigma yang lebih rendah terhadap orang dengan HIV/AIDS. Tingkat sikap stigma terhadap ODHA lebih tinggi pada masyarakat pedesaan daripada di perkotaan di Heilongjiang ${ }^{9}$

Stigma juga muncul karena ketidaktahuan masyarakat tentang informasi HIV, khususnya proses penularan HIV dan cara pencegahannya termasuk dalam penggunaan kondom. Stigma adalah penghalang terbesar untuk mencegah penularan dan pengobatan HIV. Selain itu, stigma terhadap ODHA bisa menyebabkan orang yang memiliki gejala atau diduga menderita HIV tidak mau melakukan tes untuk mengetahui status HIV. ${ }^{10}$

Munculnya stigma di masyarakat khususnya masyarakat di pedesaan juga merupakan salah satu kendala yang dihadapi dalam penanganan kasus HIV/AIDS. Dalam hidup bermasyarakat, stigma menjadi penghalang ODHA untuk melakukan aktivitas sosial. ODHA menutup diri serta cenderung tidak bersedia berinteraksi dengan keluarga, teman, dan tetangga. Hal ini disebabkan karena sebagian 
masyarakat menganggap bahwa orang dengan HIV positif merupakan orang yang menyimpang seperti perempuan pekerja seks komersial, menggunakan narkoba, dan homoseksual. Kelompok ini juga dianggap memengaruhi epidemi HIV/AIDS dan membuat masyarakat menjadi menolak dan membenci ODHA.

Pemberian informasi yang benar dan lengkap terkait HIV adalah salah satu cara yang efektif untuk menjelaskan tentang pencegahan dan penularan HIV. Seseorang dengan pengetahuan yang baik dan benar terkait HIV dapat menurunkan ataupun menghilangkan stigma pada ODHA. Persepsi masyarakat terhadap penderita HIV memiliki pengaruh yang signifikan terhadap sikap dan perilaku memberikan stigma. ${ }^{10}$

Keluarga dan masyarakat desa masih memegang teguh aturan dan tabu sosial yang ketat. Aturanaturan dan tabu-tabu sosial yang ketat menyebabkan pergaulan pada remaja desa kurang bebas. Remaja putri pedesaan dibatasi hal-hal tabu dalam pergaulannya dengan teman laki-łaki. Kontrol sosial serta aturan yang lebih ketat di desa serta adanya pengawasan orang tua terhadap anak mengurangi kemungkinan remaja desa untuk melakukan perilaku seksual yang menyimpang. ${ }^{12} \mathrm{Hal}$ ini menjadi rendahnya penularan HIV/AIDS dikalangan masyarakat desa. Disisi lain karena pengetahuan seks masih dianggap tabu, dapat menyebabkan kesalahpahaman dalam pencegahan dan penularan HIV/AIDS pada masyarakat pedesaan.

Keluarga adalah orang terdekat yang berinteraksi dengan ODHA. Menurut hasil penelitian, lebih banyak keluarga memiliki sikap yang positif terhadap ODHA dibandingkan dengan yang memberikan sikap negatif terhadap ODHA. Perilaku keluarga yang memberikan stigma ODHA dapat memperkuat diskriminasi serta penolakan dari masyarakat. Stigma pada ODHA disebabkan karena keluarga merasa malu jika mengetahui salah satu anggota keluarga adalah seorang penderita HIV sehingga dikucilkan dari keluarga. Ketakutan akan diperlakukan secara berbeda membuat ODHA sulit membuka diri dengan orang lain dan takut untuk berbagi pengalamannya, bahkan jika dia sakit. ${ }^{13}$ Sebaliknya, dukungan dari orang di sekitar ODHA berdampak pada peningkatan pemanfaatan pelayanan kesehatan. Dukungan sosial membuat penderita HIV tidak merasa sendiri, merasa disayangi dan mereka lebih berpeluang untuk menggunakan pelayanan Kesehatan atau meningkatkan kepatuhan pengobatan atau terapi antiretroviral (ARV). Keterbukaan dan rasa nyaman yang dirasakan ODHA membuat mereka lebih mudah untuk menerima informasi. ${ }^{8}$

Selain keluarga, tokoh masyarakat adalah salah satu faktor lingkungan sosial memiliki peranan penting dalam mengurangi stigma terhadap ODHA. Seseorang tokoh masyarakat memberikan stigma terhadap ODHA, masyarakat di sekitarnya memiliki kemungkinan juga akan terpengaruh untuk melakukan hal yang sama. Reaksi masyarakat terhadap ODHA memiliki efek besar pada ODHA. ${ }^{14}$

Tokoh masyarakat berperan penting dalam menurunkan terjadinya stigma dan diskriminasi terhadap ODHA karena tokoh tersebut merupakan role model atau contoh yang biasanya menjadi panutan masyarakat, terutama bagi masyarakat di daerah pedesaan. Tindakan dan sikap mereka dijadikan referensi oleh masyarakat dalam mengubah perilaku mereka, termasuk yang terkait dengan penularan HIV, dan menurunkan stigma terhadap ODHA. Oleh karena itu, pemberian informasi yang komprehensif tentang HIV/AIDS kepada tokoh masyarakat menjadi sangat penting dilakukan oleh petugas kesehatan, agar tokoh masyarakat dapat menularkan dan menyebarkan informasi yang benar kepada masyarakat, termasuk tentang menghilangkan stigma terhadap ODHA.

\section{Kesimpulan}

Berdasarkan hasil penelitian ini, maka dapat disimpulkan sebagai berikut :

1. Ada perbedaan signifikan pengetahuan tentang HIV/AIDS antara masyarakat perkotaan dan pedesaan di Sulawesi Selatan dimana mean pengetahuan masyarakat perkotaan lebih tinggi 
dibandingkan masyarakat pedesaan.

2. Tidak ada perbedaan signifikan sikap negosiasi berhubungan seksual antara masyarakat perkotaan dan pedesaan di Sulawesi Selatan.

3. Ada perbedaan signifikan sumber informasi antara masyarakat perkotaan dan pedesaan di mana nilai mean masyarakat perkotaan lebih tinggi dibandingkan mean masyarakat perkotaan.

4. Ada perbedaan signifikan Stigma atau Deskriminasi terhadap Orang dengan HIVAIDS pada Masyarakat Perkotaan dan Pedesaaan Provinsi Sulawesi Selatan dimana stigma dan diskriminasi masih lebih tinggi dipedesaan dibandingakn dengan masyarakat perkotaan

\section{Saran}

1. Diharapkan peran BKKBN dalam mengkampanyekan pencegahan penularan HIV/AIDS sejak dini melalui program generasi berencana atau "Goes to School" untuk menjauhkan anak didik dari permasalahan remaja melalui melalui metode peer education yang bersifat youth friendly.

2. Melalui Program KKBPK khususnya didaerah pedesaan, peran BKKBN sangat diharapkan dalam meningkatkan pengetahuan masyarakat secara komprehensip sehingga tidak lagi menimbulkan kesalahpahaman persepsi tentang cara penularan HIV dan meluruskan mitos tentang penularan HIV/AIDS agar tidak terjadi kekhawatiran dan ketakutan masyarakat terhadap ODHA.

3. Diharapkan kepada Dinas Kesehatan dan semua intansi pemerintah yang terkait serta Lembaga Swadaya Masyarakat (LSM) lebih meningkatkan sosialisai dan pemahaman kepada masyarakat tentang HIVAIDS khususnya di daerah pedesaan, karena kesalahpahaman pemahaman tentang penularan HIV/AIDS akan menimbulkan stigma dan diskriminasi terhadap ODHA.

4. Diharapkan kepada tokoh masyarakat, tokoh adat dan pemuka agama berperan aktif dalam menurunkan terjadinya stigma dan diskriminasi terhadap ODHA karena tokoh-tokoh lokal tersebut merupakan model atau contoh yang biasanya menjadi panutan masyarakat, terutama pada masyarakat di daerah pedesaan.

5. HIV/AIDS adalah permasalahan yang komplek sehingga dibutuhkan kerjasama semua pihak bukan hanya petugas kesehatan tetapi semua interdisiplin ilmu, multidisiplin sampai pada tahap transdisiplin ilmu sehingga mampu menyelesaikan sampai akar permasalahannya.

\section{Daftar Pustaka}

1. World Health Organization (WHO). 2015. Reproductive Health and Research. Sexually transmitted and other reproductive tract infections: a guide to essential practice.

2. Bearinger LH, Sieving RE, Ferguson J, Sharma V. Global perspectives on the sexual and reproductive health of adolescents: patterns, prevention, and potential. Lancet. 2017;369(9568):1220-31.

3. Kemenkes RI. 2016. Laporan Situasi Perkembangan HIV/AIDS dan PIMS sampai dengan Desember 2016. Diambil dari Ditjen Penanggulangan Pengendalian Penyakit \& Penyehatan Lingkungan.Website :http://spiritia.or.id/Stats/detailstat.php?no=8

4. World Health Organization (WHO). 2018. Number of people (all ages) living with HIV Estimates by WHO region. Diambil dari World Health Organization. Website: https://www.who.int/hiv/data/en/ 
5. Keluarga Berencana Nasional, 2018. Survei Demografi dan Kesehatan Indonesia (SDKI) 2017. Provinsi Sulawesi Selatan. Perwakilan Badan Kependudukan dan Keluarga Berencana Nasional Provinsi Sulawesi Selatan. xxxv, 524 hlm. ; 21 cm.. ISBN 978-602-316-139-3.

6. Rochmi, N. 2018. Stigma negatif, anak pengidap HIV dilarang sekolah. Website :https://beritagar.id/artikel/berita/stigma-negatif-anak-pengidap-hiv-dikeluarkan-darisekolah

7. Rohman, D. 2014. Implikasi Mobilitas Penduduk Dan Gaya Hidup Seksual Terhadap Penularan HIV/AIDS.Jurusan Ilmu Kesehatan Masyarakat, Fakultas Ilmu Keolahragaan, Universitas Negeri Semarang, Indonesia. Jurnal KEMAS 9 (2) 169-176. ISSN 1858-1196.

8. Ma'rif W, A., 2017. Diskriminasi Orang dengan HIV/AIDS (Studi Kasus Kelompok Dukungan Sebaya (KDS) Smile Plus Temanggung). Skripsi. Program Studi Ilmu Kesejahtraan Sosial, Fakultas Dakwah dan Komunikasi Universitas Islam Negeri Suan Kalijaga, Yogyakarta.

9. Xin Li et al. 2017. Factors Associated With Stigma Attitude Towards People Living With Hiv Among General Individuals In Heilongjiang, Northeast China. Disinfeksi Bmc Dis . 2017; 17: 154.. Doi: 10.1186 / S12879-017-2216-0

10. Zahroh, S Dkk. 2015. Stigma Masyarakat Terhadap Orang Dengan HIV/AIDS. Program Studi Magister Promosi Kesehatan Fakultas Kesehatan Masyarakat Universitas Diponegoro. Jurnal Kesehatan Masyarakat Nasional Vol. 9, No. 4, Mei 2015

11. Wahyu, I. 2013. Pengaruh Pengetahuan, Sikap, Dan Motivasi Diri Terhadap Perilaku Pencegahan HIV/AIDS Pada Siswa-Siswi SMA Perkotaan Di Kabupaten Sragen. Progran Studi Kesehatan Masyarakat Fakultas Ilmu Kesehatan Universitas Muhammadiyah Surakarta

12. Sarwono. 2011. Psikologi Remaja.Edisi Revisi. Jakarta: Rajawali Pers

13. Ni'mal, B. 2018. Prediktor Sikap Stigma Dan Diskriminasi Terhadap Orang Dengan HIV/AIDS Di Kabupaten Jember. Bagian Epidemiologi Dan Biostatistika Kependudukan, Fakultas Kesehatan Masyarakat Universitas Jember

14. Triana, N. 2016. Perbedaan Perilaku Seksual pada Remaja yang Bertempat Tinggal di Desa dan di Kota. Diambil dari Universitas Sanata Dharma. Yogyakarta.Website :http://repository.usd.ac.id/30110/2/99114_Full\%5B1\%5D.pdf \ 